\title{
Fighting COVID-19 spread among nursing home residents even in absence of molecular diagnosis: a retrospective cohort study.
}

\author{
Alessio Strazzulla ( $\square$ alessiostrazzulla@yahoo.it) \\ Centre Hospitalier de Melun https://orcid.org/0000-0003-0199-3449 \\ Paul Tarteret \\ Centre Hospitalier de Melun \\ Maria Concetta Postorino \\ Centre Hospitalier de Melun \\ Marie Picque \\ Centre Hospitalier de Melun \\ Astrid de Pontfarcy \\ Centre Hospitalier de Melun \\ Nicolas Vignier \\ Centre Hospitalier de Melun \\ Catherine Chakvetadze \\ Centre Hospitalier de Melun \\ Coralie Noel \\ Centre Hospitalier de Melun \\ Cecile Drouin \\ Centre Hospitalier de Melun \\ Zine Eddine Benguerdi \\ Centre Hospitalier de Melun \\ Sylvain Diamantis \\ Centre Hospitalier de Melun
}

\section{Research Article}

Keywords: SARS-Cov2, COVID-19, nursing home, not respiratory symptoms, confinement, death

Posted Date: August 4th, 2020

DOI: https://doi.org/10.21203/rs.3.rs-51305/v1

License: (c) (i) This work is licensed under a Creative Commons Attribution 4.0 International License. Read Full License 


\section{Abstract}

Background Access to molecular diagnosis was limited out-of-hospital in France during the 2020 coronavirus disease 2019 (COVID19) epidemic. This study describes the evolution of COVID-19 outbreak in a nursing home in absence of molecular diagnosis.

Methods A monocentric prospective study was conducted in a French nursing home from March $17^{\text {th }}, 2020$ to June $11^{\text {th }}, 2020$. Because of lack of molecular tests for severe acute respiratory syndrome 2 (SARS-Cov2) infection, probable COVID-19 cases were early identified considering only respiratory and not-respiratory symptoms and therefore preventing measures and treatments were enforced. Once available, serology tests were performed at the end of the study.

A chronologic description of new cases and deaths was made together with a description of COVID-19 symptoms. Data about personal characteristics and treatments were collected and the following comparisons were performed: i) probable COVID-19 cases $v s$ asymptomatic residents; ii) SARS-Cov2 seropositive residents $v s$ seronegative residents.

Results Overall, 32/66 (48.5\%) residents and 19/39 (48.7\%) members of health-care personnel were classified as probable COVID-19 cases. A total of 34/61 (55.7\%) tested residents resulted seropositive. Death occurred in 4/66 (6\%) residents. Diagnosis according to symptoms had $65 \%$ of sensitivity, $78 \%$ of specificity, $79 \%$ of positive predictive value and $64 \%$ of negative predictive value.

In resident population, the following symptoms were registered: 15/32 (46.8\%) lymphopenia, $15 / 32$ (46.8\%) fever, $8 / 32$ (25\%) fatigue, $8 / 32$ (25\%) cough, $6 / 32$ (18.8\%) diarrhoea, 4/32 (12.5\%) severe respiratory distress requiring oxygen therapy, 4/32 (12.5\%) fall, $3 / 32$ (9.4\%) conjunctivitis, $2 / 32$ (6.3\%) abnormal pulmonary noise at chest examination and 2/32 (6,25\%) abdominal pain.

Probable COVID-19 cases were older (81.3 vs $74.9 ; \mathrm{p}=0.007)$ and they had higher prevalence of atrial fibrillation $(8 / 32,25 \%$ vs $2 / 34$, $12 \%$; $\mathrm{p}=0.030)$; insulin treatment $(4 / 34,12 \%$ vs $0,0 \% ; \mathrm{p}=0.033)$ and positive SARS-Cov2 serology $(22 / 32,69 \%$ vs $12 / 34,35 \%$; $p=0.001)$ than asymptomatic residents. Seropositive residents had lower prevalence of diabetes $(4 / 34,12 \% v s 9 / 27,33 \% ; p=0.041)$ and angiotensin-converting-enzyme inhibitors' intake $(1 / 34,1 \%$ vs $5 / 27,19 \% ; \mathrm{p}=0.042)$.

Conclusions During SARS-Cov2 epidemic, early detection of respiratory and not-respiratory symptoms allowed to enforce extraordinary measures. They achieved limiting contagion and deaths among nursing home residents, even in absence of molecular diagnosis.

\section{Introduction}

Since coronavirus disease 2019 (COVID-19) worldwide epidemic begun in China at the end of 2019, it caused 9,653,048 new diagnosis and 491,128 deaths by June 27th, 2020 [1]. Among them, 162,936 cases and 29,778 deaths occurred in France [2]. COVID19 diagnosis is based on the association of symptoms and epidemiology criteria (probable COVID-19 case) with molecular tests (confirmed COVID-19 case) [3]. However, the use of molecular tests is limited by cost, lack of polymerase chain reaction (PCR) detection kits and need of well trained health personnel for correct specimen collection. In particular, the dramatic case escalation in many countries made impossible to perform severe acute respiratory syndrome coronavirus 2 (SARS-Cov2) PCR in any suspected cases. These problems affected high income as well as low income countries. Moreover, serology tests cannot substitute PCR because SARS-Cov2 antibodies are produced over days to weeks after infection and consequently they are recommended only for epidemiologic purposes [4].

The median age at death for COVID-19 was 82 and 80 years in Spain and Italy, respectively $[5,6]$. It suggested that preventing measures needed to be reinforced in places with high concentration of seniors, namely hospitals and nursing homes [7]. Unfortunately, many outbreaks in nursing homes were reported with disastrous consequences for their residents. In the United States during a twenty-one-daylong period in March 2020, COVID-19 outbreak occurred in two nursing homes at King and Snohomish Counties (Washington) and it was responsible of 101/118 (85.5\%) confirmed cases and 34/101 (33.7.2\%) deaths among residents [8]. In France 37,995 confirmed or possible cases and 10,488/37,995 (27.6\%) deaths among nursing home residents occurred by June 26th, 2020 [2].

On March 13th, 2020, extraordinary measures were applied in a nursing home in the Ile de France region in France, including: obligation of protective mask use by health care personnel, prohibition of visit by patients' families, obligation of in-room meal 
consumption, and training of health personnel for self-recognition of COVID-19 symptoms. These measures were enforced with the purpose of reducing the risk of contagious from visitors and minimize the risk of intramural transmission. On March 16th, 2020, a member of the health care personnel was tested positive to SARS-Cov2 PCR after three days of COVID-19 symptoms. This event produced the activation of the inner surveillance system and a quick epidemiologic inquiry was conducted. It individuated 21 close contacts, including four symptomatic nursing home residents who were quickly isolated with implementation of contact and air precautions. Only one patient was tested positive while other three patients did not receive test. This choice was motivated by the necessity of SARS-Cov2 PCR sparing because of lack of reagents in the entire French territory and the consequent prioritisation for in-hospital diagnosis. All other contact cases, including health care personnel, were isolated at home. The first three consecutive symptomatic members of health care personnel were tested positive to SARS-Cov2.

This study describes the evolution of contagion during the COVID-19 outbreak in a French nursing home and all measures enforced to limit COVID-19 morbidity in a context of lack of molecular tests. Moreover, residents' clinical characteristics were compared to individuate possible risk factors for COVID-19 contagion and death.

\section{Materials And Methods}

A monocentric prospective study was conducted. The study was settled in a public nursing home located in the Ile de France region in France, accounting for 66 beds. The entire population of residents was followed from March 17th, 2020 to June 11 th, 2020 after a member of the health care personnel had been tested positive to SARS-Cov2 from nasopharyngeal swab on March 16 th, 2020 (positive result received on March 17th, 2020).

The study was conducted in accordance with Declaration of Helsinki and national and institutional standards. According with the current French legislation, approval by the local ethic committee was not demanded because a non-interventional research was conducted; meaning that all procedures and drugs administrated did not differed from daily clinical practice $[9,10]$. Patients were informed about the inclusion in a non-interventional retrospective study. No patient or legal representative expressed opposition for the inclusion in this study.

After the first confirmed COVID-19 case among health care personnel, the first three consecutive symptomatic members of health care personnel were tested and they resulted positive to SARS-Cov2. These results justified the prosecution of the extraordinary measures, the surveillance for the rest of nursing home population (residents and health care personnel) and the reinforcement of the nursing staff. Subsequently, test for SARS-Cov2 was not systemically proposed to members of health care personnel and SARSCov2 molecular test was only administrated according to medical decision case by case. Probable COVID-19 cases among health care personnel were systemically confined at home.

During the time-frame analysed, all residents who developed COVID-19 symptoms after June 17th, 2020 were classified as "suspected cases" and they were isolated with implementation of contact and air precautions and room confinement, according with recommendations of the Health Regional Agency (Agence Régionale de Santé ou ARS) [11]. All suspected cases were tested negative for influenza virus infection by rapid flu test. Only one suspected case was tested for COVID-19 by nasopharyngeal swab and classified as "confirmed case" after positive result of SARS-Cov2 PCR, according with International definition [3]. The patient was randomly selected among the first four suspected cases with the purpose of identifying a possible cluster of COVID-19 and justifying the continuation of isolation for suspected cases and surveillance for the rest of nursing home population (residents and health care personnel). No other molecular tests were performed among nursing home residents because of the necessity of SARSCov2 PCR sparing as a consequence of the lack of reagents in the entire French territory and prioritisation for in-hospital diagnosis. Once available, serology test was performed retrospectively in the entire resident population at the end of the study. Serology test were performed from June 8th, 2020 to June 11th, 2020 using the Roche® SARS-CoV-2 assay [12].

All COVID-19 suspected cases were re-classified as "probable cases" according with the French survey protocol among nursing homes. This protocol defines probable case not only in presence of acute respiratory illness or fever (and no other aetiology fully explains the clinical presentation) but also in presence of any other symptom compatible with COVID-19 (and no other aetiology fully explains the clinical presentation). According with this protocol all probable cases were signalled to ARS [13]. The following signs and symptoms were used for the definition of probable case: fever, severe respiratory distress requiring oxygen therapy, cough, conjunctivitis, nasal congestion, abnormal pulmonary noise at chest examination, diarrhoea, abdominal pain, fatigue, fall, 
neurologic troubles, lymphopeniain the complete blood count [14-17]. Fall and neurologic troubles were included among symptoms because they could reveal a marked asthenia. Sensitivity and sensibility of diagnosis based only on symptoms were calculated using serology as reference.

At the end of the study period, patients were distributed in groups according to the following criteria: i) presence of COVID-19 symptoms (symptomatic probable COVID-19 case group and asymptomatic resident group); ii) SARS-Cov2 serology results (seropositive resident group and seronegative resident group).

Residents' files were analysed to collect the following personal parameters and co-morbidities: age, gender, grade of autonomy, not normal nutritional status (obesity or underweight), 2019-2020 seasonal flu vaccination, arterial hypertension, heart failure, atrial fibrillation, ischemic heart disease, thromboembolic venous disease, chronic obstructive pulmonary disease, solid or hematologic neoplasia, chronic kidney disease and diabetes. For the grade of autonomy, the autonomy, gerontorology, iso-resources group (autonomie, gerontology groupe iso resources or AGGIR) panel was used because it is the actual legal instrument for evaluating autonomy in aged people in France. According to this panel, the minimal AGGIR grade 1 is given to elderly patients who are confined at bed and needing a continuous surveillance while the maximal AGGIR grade 6 is given to patients with preserved autonomy [18]. Chronic kidney disease was defined for estimated glomerular filtration rate $<60 \mathrm{ml} / \mathrm{min}$ [19]. For nutritional status, obesity and underweight were defined for values of body mass index $(\mathrm{BMI})>24.9$ and $\mathrm{BMI}<18.5$, respectively [20]. Also, data about the following co-medications were collected: loop diuretics, thiazide diuretics, a-blocker antihypertensive drugs, calcium channel blockers, angiotensin converting enzyme (ACE) inhibitors, angiotensin II receptor blockers, $\beta$-blockers, insulin, metformin and other anti-diabetic drugs.

The following analysis were performed: i) chronologic description of new probable cases and deaths from March 17th, 2020 to June 11th, 2020 among residents and health care personnel; ii) sensitivity and specificity calculation for diagnosis based only on symptoms; iii) description of COVID-19 symptoms in probable cases among residents; iv) between-group (probable COVID-19 cases among residents $v s$ asymptomatic residents) comparison of personal parameters, co-morbidities and co-medications; v) betweengroup (seropositive resident group vs seronegative resident group) comparison of personal parameters, co-morbidities and comedications.

The following statistic tests were performed: $\chi^{2}$-test for qualitative variables and Student's T-test for quantitative variables. Quantitative variables were presented in the text as mean values. $R$, the language for statistical computing (Vienna, Austria, https://www.r-project.org/) was used to perform all statistical analysis. Nominal statistical significance was set at $p<0.050$.

\section{Results}

During the study period, 19/39 (48.7\%) probable COVID-19 cases occurred among health care personnel. Among them, 6/19 (31.5\%) were tested positive by SARS-Cov2 PCR and re-classified as confirmed cases. Overall, 66 residents were followed during the same period, 32/66 (48.5\%) were identified as probable COVID-19 cases and one of them was tested for COVID-19 and re-classified as confirmed case after positive result of SARS-Cov2 PCR. Death occurred in 3/32 (9.4\%) probable cases and 1/34 (2.9\%) asymptomatic resident, accounting for $4 / 66(6 \%)$ residents. Figure 1 shows evolution of new probable cases and deaths among health care personnel and residents.

Serology tests were performed at the end of the study in 61/66 (92.4\%) residents, 4/66 (6\%) were not tested because they died before the end of the study and one patient refused the test. Overall, 34/61 (55.7\%) residents resulted seropositive. A total of 28/32 (87.5\%) probable COVID-19 cases were tested; among them, $22 / 28$ (78.6\%) were positive and 6/28 (21.4\%) were negative. Of the $33 / 34(97.1 \%)$ asymptomatic patients who received serology test, $12 / 33(36.4 \%)$ were positive and 21/33 (63.6\%) were negative. Overall, the presence clinical symptoms for diagnosis of COVID-19 (retrospectively confirmed by serology test) had $65 \%$ of sensitivity, $78 \%$ of specificity, $79 \%$ of positive predictive value and $64 \%$ of negative predictive value.

Among probable COVID-19 cases in resident population, 15/32 (46.8\%) had lymphopenia, 15/32 (46.8\%) fever, 8/32 (25\%) fatigue, $8 / 32(25 \%)$ cough, $6 / 32(18.8 \%)$ diarrhoea, $4 / 32$ (12.5\%) severe respiratory distress requiring oxygen therapy, $4 / 32(12.5 \%)$ fall, $3 / 32$ $(9.4 \%)$ conjunctivitis, $2 / 32(6.3 \%)$ abnormal pulmonary noise at chest examination and 2/32 $(6,25)$ abdominal pain. No one experienced nasal congestion or neurologic troubles.

Page 4/12 
At the between group analysis, probable COVID-19 cases were older $(81.3 v s 74.9 ; p=0.007)$ and they had higher prevalence of atrial fibrillation $(8 / 32,25 \%$ vs $2 / 34,12 \% ; p=0.030)$; insulin treatment $(4 / 34,12 \% v s 0,0 \% ; p=0.033)$ and positive SARS-Cov2 serology $(22 / 32,69 \%$ vs $12 / 34,35 \% ; p=0.001)$ than asymptomatic patients. Seropositive residents had lower prevalence of diabetes $(4 / 34$, $12 \%$ vs $9 / 27,33 \% ; p=0.041)$, ACE inhibitors' intake $(1 / 34,1 \%$ vs $5 / 27,19 \% ; p=0.042)$ and treatment by anti-diabetic drugs other than insulin and metformin $(0 / 34,0 \% v s 4 / 27,15 \% ; p=0.020)$ than seronegative residents. No other significant differences were reported, as shown in Table 1. 
Table 1

characteristics of the resident population

\begin{tabular}{|c|c|c|c|c|c|c|c|}
\hline \multirow[t]{2}{*}{ CHARACTERISTICS } & $\begin{array}{l}\text { OVERALL } \\
\text { POPULATION }\end{array}$ & $\begin{array}{l}\text { PROBABLE } \\
\text { COVID-19 } \\
\text { CASES }\end{array}$ & $\begin{array}{l}\text { ASYMPTOMATIC } \\
\text { RESIDENTS }\end{array}$ & \multirow[t]{2}{*}{$\begin{array}{l}\text { p- } \\
\text { value }\end{array}$} & $\begin{array}{l}\text { COVID-19 } \\
\text { SEROPOSITIVE }\end{array}$ & $\begin{array}{l}\text { COVID-19 } \\
\text { SERONEGATIVE }\end{array}$ & \multirow[t]{2}{*}{$\begin{array}{l}\mathrm{p}- \\
\text { value }\end{array}$} \\
\hline & $(n=66)$ & $(n=32)$ & $(n=34)$ & & $(n=34)$ & $(n=27)$ & \\
\hline \multicolumn{8}{|l|}{$\begin{array}{l}\text { Demographical } \\
\text { parameters }\end{array}$} \\
\hline Age [mean (SD] & 78.27 (10.64) & $\begin{array}{l}81.87 \\
(10.3)\end{array}$ & $74.88(9.96)$ & 0.007 & 79.17 (11.19) & $75.07(9.33)$ & 0.132 \\
\hline $\begin{array}{l}\text { Female gender [n } \\
(\%)]\end{array}$ & $47(71)$ & $24(75)$ & $23(68)$ & 0.50 & $24(70.5)$ & $19(70)$ & 1 \\
\hline \multicolumn{8}{|l|}{ Grade of autonomy } \\
\hline AGGIR 1 [n (\%)] & $6(9)$ & $3(9)$ & $3(9)$ & \multirow[t]{6}{*}{0.16} & $5(15)$ & $0(0)$ & \multirow[t]{6}{*}{0.102} \\
\hline AGGIR 2 [n (\%)] & $17(26)$ & $13(41)$ & $4(12)$ & & $10(29)$ & $5(19)$ & \\
\hline AGGIR 3 [n (\%)] & $22(33)$ & $9(28)$ & $13(38)$ & & $8(24)$ & $13(48)$ & \\
\hline AGGIR 4 [n (\%)] & $17(26)$ & $6(19)$ & $11(32)$ & & $10(29)$ & $6(22)$ & \\
\hline AGGIR 5 [n (\%)] & $4(6)$ & $1(3)$ & $3(9)$ & & $1(3)$ & $3(11)$ & \\
\hline AGGIR 6 [n (\%)] & $0(0)$ & $0(0)$ & $0(0)$ & & $0(0)$ & $0(0)$ & \\
\hline \multicolumn{8}{|l|}{ Nutritional status } \\
\hline Obesity* [n (\%)] & $18(27)$ & $7(22)$ & $11(32)$ & 0.34 & $8(24)$ & $10(37)$ & 0.25 \\
\hline $\begin{array}{l}\text { Underweight } * \star \text { [n } \\
(\%)]\end{array}$ & $10(15)$ & $7(22)$ & $3(9)$ & 0.14 & $7(20.5)$ & $2(7)$ & 0.15 \\
\hline \multicolumn{8}{|l|}{ Vaccinations } \\
\hline $\begin{array}{l}\text { Flu vaccination [n } \\
(\%)]\end{array}$ & $62(94)$ & $29(91)$ & $33(97)$ & 0.27 & $32(94)$ & $25(92.5)$ & 0.81 \\
\hline \multicolumn{8}{|l|}{ Co-morbidities } \\
\hline $\begin{array}{l}\text { Arterial } \\
\text { hypertension [n } \\
(\%)]\end{array}$ & $39(59)$ & $20(62.5)$ & $19(56)$ & 0.58 & $20(59)$ & $17(63)$ & 0.74 \\
\hline Heart failure [n (\%)] & $2(3)$ & $2(6)$ & $0(0)$ & 0.14 & $1(3)$ & $1(4)$ & 0.87 \\
\hline $\begin{array}{l}\text { Atrial fibrillation [n } \\
(\%)]\end{array}$ & $10(15)$ & $8(25)$ & $2(6)$ & 0.030 & $5(15)$ & $3(11)$ & 0.68 \\
\hline $\begin{array}{l}\text { Ischemic heart } \\
\text { disease [n (\%)] }\end{array}$ & $2(3)$ & $1(3)$ & $1(3)$ & 0.96 & $1(3)$ & $1(4)$ & 0.87 \\
\hline TVP [n (\%)] & $9(14)$ & $5(16)$ & $4(12)$ & 0.64 & $5(15)$ & $3(11)$ & 0.68 \\
\hline COPD [n (\%)] & $5(7.5)$ & $3(9)$ & $2(6)$ & 0.59 & $3(9)$ & $1(4)$ & 0.42 \\
\hline Cancer*** $[n(\%)]$ & $3(4.5)$ & $2(6)$ & $1(3)$ & 0.51 & $3(9)$ & $0(0)$ & 0.11 \\
\hline CKD [n (\%)] & $1(1.5)$ & $1(3)$ & $0(0)$ & 0.30 & $1(3)$ & $0(0)$ & 0.37 \\
\hline Diabetes, [n (\%)] & $13(20)$ & $7(22)$ & $6(18)$ & 0.66 & $4(12)$ & $9(33)$ & 0.041 \\
\hline
\end{tabular}

LEGEND: *defined as body mass index $>24.9$; $* \star$ defined as body mass index $<18.5$; ***including both solid and haematological malignancies; $* \star \star$ not applicable for serology group analysis because 4 patients died before receiving serology test; $A C E=$ angiotensin converting enzyme; AGGIR = autonomy, gerontorology, iso-resources group (autonomie, gérontologiegroupeiso resources); $\mathrm{ARB}=$ angiotensin II receptor blockers; $\mathrm{CMD}$ = chronic kidney disease; $\mathrm{COPD}$ = chronic obstructive pulmonary disease;SD = standard deviation; TVP = thromboembolic venous disease. 


\begin{tabular}{|c|c|c|c|c|c|c|c|}
\hline \multirow[t]{2}{*}{ CHARACTERISTICS } & $\begin{array}{l}\text { OVERALL } \\
\text { POPULATION }\end{array}$ & $\begin{array}{l}\text { PROBABLE } \\
\text { COVID-19 } \\
\text { CASES }\end{array}$ & $\begin{array}{l}\text { ASYMPTOMATIC } \\
\text { RESIDENTS }\end{array}$ & \multirow[t]{2}{*}{$\begin{array}{l}\mathrm{p}- \\
\text { value }\end{array}$} & $\begin{array}{l}\text { COVID-19 } \\
\text { SEROPOSITIVE }\end{array}$ & $\begin{array}{l}\text { COVID-19 } \\
\text { SERONEGATIVE }\end{array}$ & \multirow[t]{2}{*}{$\begin{array}{l}\mathrm{p}- \\
\text { value }\end{array}$} \\
\hline & $(n=66)$ & $(n=32)$ & $(n=34)$ & & $(n=34)$ & $(n=27)$ & \\
\hline \multicolumn{8}{|l|}{ Co-medications } \\
\hline $\begin{array}{l}\text { Loop diuretics [n } \\
(\%)]\end{array}$ & $8(12)$ & $6(19)$ & $4(12)$ & 0.43 & $5(15)$ & $3(11)$ & 0.68 \\
\hline $\begin{array}{l}\text { Thiazide diuretics } \\
\text { [n (\%)] }\end{array}$ & $6(9)$ & $2(6)$ & $4(12)$ & 0.43 & $3(9)$ & $3(11)$ & 0.79 \\
\hline a-blockers [n (\%)] & $3(4.5)$ & $1(3)$ & $2(6)$ & 0.59 & $2(6)$ & $1(4)$ & 0.69 \\
\hline $\begin{array}{l}\text { Calcium channel } \\
\text { blockers [n (\%)] }\end{array}$ & $25(38)$ & $13(41)$ & $12(35)$ & 0.65 & $13(38)$ & $10(37)$ & 0.92 \\
\hline $\begin{array}{l}\text { ACE inhibitors [n } \\
(\%)]\end{array}$ & $6(9)$ & $3(9)$ & $3(9)$ & 0.94 & $1(3)$ & $5(19)$ & 0.042 \\
\hline ARB [n (\%)] & $11(17)$ & $7(22)$ & $4(12)$ & 0.27 & $6(18)$ & $5(19)$ & 0.93 \\
\hline ß-blockers [n (\%)] & $11(17)$ & $7(22)$ & $4(12)$ & 0.27 & $6(18)$ & $5(19)$ & 0.93 \\
\hline Insulin [n (\%)] & $4(6)$ & $4(12)$ & $0(0)$ & 0.033 & $3(9)$ & $1(4)$ & 0.42 \\
\hline Metformin [n (\%)] & $12(18)$ & $8(25)$ & $4(12)$ & 0.16 & $5(15)$ & $6(22)$ & 0.45 \\
\hline $\begin{array}{l}\text { Other anti-diabetic } \\
\text { drugs [n (\%)] }\end{array}$ & $4(6)$ & $1(3)$ & $3(9)$ & 0.33 & $0(0)$ & $4(15)$ & 0.020 \\
\hline \multicolumn{8}{|l|}{$\begin{array}{l}\text { SARS-Cov2 } \\
\text { serology }\end{array}$} \\
\hline Not realised [n (\%)] & $5(7.5)$ & $4(12)$ & $1(3)$ & \multirow[t]{3}{*}{0.001} & $0(0)$ & $0(0)$ & \multirow[t]{3}{*}{ NA } \\
\hline Negative [n (\%)] & $27(41)$ & $6(19)$ & $21(62)$ & & $0(0)$ & 27 (100) & \\
\hline Positive [n (\%)] & $34(51.5)$ & $22(69)$ & $12(35)$ & & $34(100)$ & $0(0)$ & \\
\hline \multicolumn{8}{|l|}{ Death**** } \\
\hline No [n (\%)] & $62(94)$ & $31(91)$ & 31 (97) & \multirow[t]{2}{*}{0.27} & NA & NA & \multirow[t]{2}{*}{ NA } \\
\hline Yes [n (\%)] & $4(6)$ & $3(9)$ & $1(3)$ & & NA & NA & \\
\hline $\begin{array}{l}\text { LEGEND: *defined as } \\
\text { malignancies; } * \star \star \text { no } \\
\text { angiotensin converti } \\
\text { resources); ARB = an } \\
\text { disease;SD = standa }\end{array}$ & $\begin{array}{l}\text { body mass index } \\
\text { applicable for se } \\
\text { g enzyme; AGGIF } \\
\text { iotensin II recept } \\
\text { deviation; TVP }\end{array}$ & $\begin{array}{l}>24.9 ;{ }^{* *} \text { defi } \\
\text { ology group a } \\
=\text { autonomy, } \\
\text { r blockers;Ci } \\
\text { thromboemb }\end{array}$ & $\begin{array}{l}\text { d as body mass in } \\
\text { alysis because } 4 \text { pa } \\
\text { erontorology, iso-res } \\
=\text { chronic kidney d } \\
\text { lic venous disease. }\end{array}$ & $\begin{array}{l}\text { ex }<18.5 \\
\text { ients die } \\
\text { urces gl } \\
\text { ease;CC }\end{array}$ & $\begin{array}{l}\star \star \star \text { including both } \\
\text { d before receiving } \\
\text { oup (autonomie, } g \\
P D=\text { chronic obstr }\end{array}$ & $\begin{array}{l}\text { solid and haematol } \\
\text { erology test; } A C E= \\
\text { rontologiegroupeis } \\
\text { ictive pulmonary }\end{array}$ & ogical \\
\hline
\end{tabular}

\section{Discussion}

This study showed that COVID-19 outbreak in nursing homes can be managed even in absence of molecular diagnosis. Indeed, early detection of respiratory and not respiratory symptoms and the consequent preventive measures achieved in limit contagion at $58 \%$ and deaths at $6 \%$. Besides, the between group analysis showed that that COVID-19 was associated with older age and heart diseases (atrial fibrillation).

Death rates in the entire resident population (6\%) and among probable COVID-19 cases (9\%) were low when compared with death rates among nursing home residents in France (27\% among COVID-19 confirmed or probable cases) [2]. Moreover, the rate of symptomatic patients was limited at $49 \%$ and prevalence of seropositive patients maximized at $58 \%$. We can infer that the quick isolation of probable COVID-19 cases limited the spread of SARS-Cov2 infection among other residents. 
In our study, the most frequent symptom was fever (46.8\%) and only $25 \%$ of symptomatic residents developed cough and $12.5 \%$ required oxygen support. These data showed that COVID-19 is not only a respiratory disease but rather a "systemic" disease and that COVID-19 patients are more susceptible to develop not specific symptoms rather than a respiratory disease, at least in the early symptomatic period [17]. It is critically important to consider not respiratory COVID-19 symptoms with the purpose of ensuring quick health care of ill patients and contagion containment. In particular, digestive symptoms should be monitored because patients with presence of SARS-Cov2 in faeces can be infectious and diarrhoea (18.8\% in our study) can facilitate the spread of the infection [16].

We applied the French strategy for limiting COVID-19 outbreak in nursing homes. This strategy had two main points: i) enforcement of extraordinary measures (obligation of protective mask use by all health care personnel, prohibition of visit by patient families, obligation of in-room meal consumption) with the purpose of limiting contagion from health care personnel and asymptomatic patients or visitors; ii) definition of probable COVID-19 cases not only in presence of fever and respiratory distress but also in presence of not respiratory COVID-19 symptoms. The consequent early isolation of symptomatic patients balances the loss of microbiology diagnosis due to the SARS-Cov2 PCR limiting politics currently applied in French nursing homes [13]. Notwithstanding, it persists the problem of the asymptomatic SARS-Cov2 carriers (health care personnel and residents) who is impossible to punctually detect even in case of extended use of SARS-Cov2 PCR [21]. In this context, the use of SARS-Cov2 serology can be useful only for retrospective epidemiological analysis [22].

Early detection of possible COVID-19 patients considering respiratory and non respiratory symptoms had modest sensitivity and specificity (65\% and $78 \%$, respectively) when compared to serology. However, it is difficult to extrapolate our results to other settings because COVID-19 prevalence of disease can significantly change according to geographical area and time period.

In this study, COVID-19 was associated with increased age and heart diseases (atrial fibrillation). These data are in line with the current knowledge of SARS-Cov2 infection [23,24]. The lower prevalence of ACE inhibitor intake among COVID-19 seropositive patients does not support the hypothesis that these molecules could make patients more susceptible to SARS-Cov2 infection. However, literature data still remains controversial $[25,26]$.

It could be argued that some patients with influenza virus infection could have been classified as probable COVID-19 cases because of a bias in our classification of COVID-19 cases. However, this hypothesis is unlikely because: i) rates of seasonal flu vaccination were high and not significantly different at the between-group analysis; ii) all probable COVID-19 cases were tested negative by rapid flu test by well trained health personnel at the beginning of symptoms [27]; iii) during the study period, the flu epidemic in France was clearly reducing its rate of new contagion and, for this reason, the Ile de France region was declared in "post-epidemic" phase early in March [28, 29]; the retrospective SARS-Cov2 serology analysis confirmed that a COVID-19 outbreak occurred during the study period.

This study presents several limitations: i) its monocentric design limits the comparison with studies performed in other settings; ii) the small population size limited statistical analysis; iii) the use of serology to confirm the diagnosis of COVID-19 was inaccurate because current serology tests are not the gold standard and they have a not optimal sensitivity (60-90\%) [30]; iv) absence of systematic administration of nasopharyngeal swab for SARS-Cov2 PCR prevented microbiologic diagnosis. However, SARS-Cov2 PCR has a high false negative rate, especially in the elderly, and for this reason adjunctive criteria are needed to diagnose COVID-19, such as radiological and clinical criteria [31-33]. Indeed, purpose of the study was to show the effectiveness of a strategy based on diagnosis of probable COVID-19 cases only by the detection of respiratory and not respiratory symptoms and the consequent enforcement of preventing measures and standard of care.

\section{Conclusions}

The COVID-19 outbreak in nursing homes can be managed even in absence of molecular diagnosis. Indeed, in this study contagion were limited at $58 \%$ and deaths at $6 \%$. These results are satisfactory when the worldwide health crisis in nursing homes is considered. The early diagnosis of probable COVID-19 cases based on recognition of respiratory and not respiratory symptoms (in both health care personnel and residents) was the key factor for the containment of SARS-Cov2 outbreak.

In case of lack of molecular tests, we propose a strategy of systematic confinement and early diagnosis based on the early detection of respiratory and not-respiratory symptoms. This strategy can reduce mortality and make COVID-19 a controllable 
disease rather than an inevitable doom for nursing home residents, even in absence of molecular diagnosis.

\section{List Of Abbreviations}

$\mathrm{ACE}=$ angiotensin converting enzyme

AGGIR = autonomy, gerontorology, iso-resources group (autonomie, gérontologiegroupeiso resources)

ARS $=$ Health Regional Agency (AgenceRégionale de Santê)

$\mathrm{BMI}=$ body mass index

COVID-19 = coronavirus disease 2019

$\mathrm{PCR}=$ polymerase chain reaction

SARS-Cov2 = severe acute respiratory syndrome coronavirus 2

\section{Declarations}

\section{Ethics approval and consent to participate}

According with the current French legislation, approval by the local ethic committee was not demanded because a non interventional research was conducted, meaning that all procedures and drugs administrated did not differed from daily clinical practice. A written consent form was not proposed to patients because the non interventional nature of the study required only the absence of patients' opposition, according to the French law. No patients or legal representative expressed opposition for the inclusion in this study.

\section{Funding sources}

This research did not receive any funding from public, commercial or not-for-profit organisations.

\section{Availability of data and materials}

The datasets used and/or analysed during the current study are available from the corresponding author on reasonable request.

\section{Competing interest}

The authors declare that they have no competing interests

\section{Acknowledgements}

Not applicable

\section{Author contributions}

Diamantis S contributed to the study conception and design. Material preparation and data collection were performed by Tarteret $\mathrm{P}$, Noel C, Drouin C, Picque M and Benguerdi ZE. Statistical analysis was performed by Postorino MC. The first draft of the manuscript was written by Strazzulla A. Vignier N, de Pontfarcy A, Chakvetadze C and Diamantis S commented on previous version of the manuscript. All authors read and approved the final manuscript.

\section{References}

1. World Health Organisation. Coronavirus disease 2019 (COVID-19) Situation Report - 159. Available at https://www.who.int/emergencies/diseases/novel-coronavirus-2019/situation-reports/ (last accessed on June 28 ${ }^{\text {th }}, 2020$ ) 
2. RépubliqueFrançaise :Ministère de la Santé et de la Solidarité. Carte du nombre de casen France. Available at https://dashboard.covid19.data.gouv.fr/ (French, last accessed on on June $28^{\text {th }}, 2020$ )

3. European Centre for Disease Prevention and Control. https://www.ecdc.europa.eu/en/case-definition-and-europeansurveillance-human-infection-novel-coronavirus-2019-ncov (last accessed on June $27^{\text {th }}, 2020$ )

4. World Health Organisation. https://www.who.int/emergencies/diseases/novel-coronavirus-2019/technical-guidance (last accessed on June $28^{\text {th }}, 2020$ )

5. Gobierno de España :Ministerio de ciencia e innovacion. Informe n 20 . Situación de COVID-19 enEspaña a 3 de abril de 2020. Available at sciii.es/QueHacemos/Servicios/VigilanciaSaludPublica RENAVE/EnfermedadesTransmisibles/Paginas/InformesCOVID-19.aspx (Spanish, last accessed on April $4^{\text {th }}, 2020$ )

6. IstitutoSuperiore di Sanità. Characteristics of COVID-19 patients dying in Italy Report based on available data on April 2nd, 2020. Available at https://www.epicentro.iss.it/coronavirus/(last accessed on April $\left.4^{\text {th }}, 2020\right)$

7. Tan LF, Seetharaman S. Preventing the Spread of COVID-19to Nursing Homes: Experience from a Singapore Geriatric Centre. J Am Geriatr Soc. 2020 Mar 26. doi: 10.1111/jgs.16447.

8. McMichael TM, Currie DW, Clark S, Pogosjans S, Kay M, Schwartz NG, Lewis J, Baer A, Kawakami V, Lukoff MD, Ferro J, Brostrom-Smith C, Rea TD, Sayre MR, Riedo FX, Russell D, Hiatt B, Montgomery P, Rao AK, Chow EJ, Tobolowsky F, Hughes MJ, Bardossy AC, Oakley LP, Jacobs JR, Stone ND, Reddy SC, Jernigan JA, Honein MA, Clark TA, Duchin JS : Epidemiology of Covid19 in a Long-Term Care Facilityin King County, Washington.NEngl J Med. 2020 Mar 27. doi: 10.1056/NEJMoa2005412.

9. Journal officiel de la RépubliqueFrançaise : LOI n² 2012-300 du 5 mars 2012 relative aux recherchesimpliquant la personnehumaine (1). Available at https://www.legifrance.gouv.fr/affichTexte.do? cidTexte=JORFTEXT000025441587\&categorieLien=id (French, last accessed on April $9^{\text {th }}, 2020$ )

10. Deplanque D, Sénéchal-Cohen S, Lemaire F; participants of Giens XXXII, round table n(o) 5 . French Jardé's law and European regulation on drug trials: Harmonization and implementation of new rules. Thérapie. 2017 Feb;72(1):73-80. doi: 10.1016/j.therap.2016.12.006

11. AgenceRégionale de Santé. Recommandationsrégionales covid-19. Prise en charge des personnesâgéesen EHPAD. Available at https://www.iledefrance.ars.sante.fr/coronavirus-covid-19-information-aux-professionnels-de-sante (French, last accessed April $\left.4^{\text {th }}, 2020\right)$

12. Lau CS ,Hoo SP, Yew SF, Ong SK, Lum LT, Heng PY, Tan JG, Wong MS, Aw Evaluation of an electrochemiluminescent SARSCoV-2 antibody assay J Appl Lab Med. 2020 Jul 27;jfaa134. doi: 10.1093/jalm/jfaa134.

13. RépubliqueFrançaise :Ministère de la Santé et de la Solidarité. Protocole de la surveillance active des cas de COVID-19 en EHPAD et EMS. Available at https://www.santepubliquefrance.fr/maladies-et-traumatismes/maladies-et-infectionsrespiratoires/infection-a-coronavirus/articles/infection-au-nouveau-coronavirus-sars-cov-2-covid-19-france-et-monde (last accessed on April $\left.5^{\text {th }}, 2020\right)$

14. Han C, Duan C, Zhang S, Spiegel B, Shi H, Wang W, Zhang L, Lin R, Liu J, Ding Z, Hou X.DigestiveSymptoms in COVID-19 Patients WithMildDiseaseSeverity: ClinicalPresentation, Stool Viral RNA Testing, and Outcomes. Am J Gastroenterol. 2020 Jun;115(6):916-923. doi: 10.14309/ajg.0000000000000664.

15. Liu K, Chen Y, Lin R, Han K. Clinical features of COVID-19in elderly patients: A comparison with young and middle-aged patients.J Infect. 2020 Mar 27. pii: S0163-4453(20)30116-X. doi: 10.1016/j.jinf.2020.03.005.

16. Tian Y, Rong L, Nian W, He Y. Reviewarticle: gastrointestinal features in COVID-19 and the possibility of faecal transmission.Aliment PharmacolTher. 2020 Mar 29. doi: 10.1111/apt.15731

17. Borges do Nascimento IJ, Cacic N, Abdulazeem HM, von Groote TC, Jayarajah U, Weerasekara I, Esfahani MA, Civile VT, Marusic A, Jeroncic A, Carvas Junior N, Pericic TP, Zakarija-Grkovic I, MeirellesGuimarães SM, Luigi Bragazzi N, Bjorklund M, SofiMahmudi A, Altujjar M, Tian M, Arcani DMC, O'Mathúna DP, Marcolino MS. Novel Coronavirus Infection (COVID-19) in Humans: A Scoping Reviewand Meta-Analysis.JClin Med. 2020 Mar 30;9(4). pii: E941. doi: 10.3390/jcm9040941.

18. Benaim C, Froger J, Compan B, Pélissier J. The assessment of autonomy in elderly people. Ann Readapt Med Phys.2005 Jul;48(6):336-40 (French)

19. Stevens PE, Levin A; KidneyDisease: Improving Global Outcomes Chronic Kidney Disease Guideline Development Work Group Members: Evaluation andmanagement of chronic kidney disease: synopsis of the kidney disease: improving global

Page $10 / 12$ 
outcomes 2012 clinical practice guidelines.Ann Intern Med. 2013 Jun 4;158(11):825-30. doi:10.7326/0003-4819-158-11201306040-00007

20. World health organisation. Regional office for Europe. http://www.euro.who.int/en/health-topics/disease-prevention/nutrition/ahealthy-lifestyle/body-mass-index-bmi (last accessed on April $\left.5^{\text {th }}, 2020\right)$

21. Yu X, Yang R. COVID-19 transmission through asymptomatic carriers is a challenge to containment. Influenza Other Respir Viruses. 2020 Apr 4. doi: 10.1111/irv.12743

22. Li Z, Yi Y, Luo X, Xiong N, Liu Y, Li S, Sun R, Wang Y, Hu B, Chen W, Zhang Y, Wang J, Huang B, Lin Y, Yang J, Cai W, Wang X, Cheng J, Chen Z, Sun K, Pan W, Zhan Z, Chen L, Ye F. Development and Clinical Application of A Rapid IgM-IgG Combined Antibody Test for SARS-CoV-2 Infection Diagnosis. J Med Virol. 2020 Feb 27. doi: 10.1002/jmv.25727

23. Wu Cl, Postema PG, Arbelo E, Behr ER, Bezzina CR, Napolitano C, Robyns T, Probst V, Schulze-Bahr E, Remme CA, Wilde AAM SARS-CoV-2, COVID-19and inherited arrhythmia syndromes. Heart Rhythm. 2020 Mar 31. pii: S1547-5271(20)30285-X

24. Parveen R, Sehar N, Bajpai R, Bharal Agarwal N. Association of diabetesand hypertension with disease severity in covid-19 patients: a systematic literature review and exploratory meta-analysis. Diabetes Res ClinPract. 2020:108295. doi: 10.1016/j.diabres.2020.108295.

25. Yang G, Tan Z, Zhou L, Yang M, Peng L, Liu J, Cai J, Yang R, Han J, Huang Y, He S. Effects ofAngiotensin II Receptor Blockers and ACE (Angiotensin-Converting Enzyme) Inhibitors on Virus Infection, Inflammatory Status, and Clinical Outcomes in Patients With COVID-19 and Hypertension: A Single-Center Retrospective Study. 2020 Jul;76(1):51-58. doi:

0.1161/HYPERTENSIONAHA.120.15143.

26. Fosbøl EL, Butt JH, ØstergaardL, Andersson C, Selmer C, Kragholm K, Schou M, Phelps M, Gislason GH, Gerds TA, Torp-Pedersen C, Køber Association of Angiotensin-Converting Enzyme Inhibitor or Angiotensin Receptor Blocker Use With COVID-19 Diagnosis and Mortality JAMA. 2020 Jun 19;e2011301. doi: 10.1001/jama.2020.11301

27. Merckx J, Wali R, Schiller I, Caya C, Gore GC, Chartrand C, Dendukuri N, Papenburg J: Diagnostic Accuracy of Novel and Traditional Rapid Tests for Influenza Infection Compared With Reverse Transcriptase Polymerase Chain Reaction: A Systematic Review and Meta-analysis. Ann Intern Med. 2017 Sep 19;167(6):394-409. doi: 10.7326/M17-0848.

28. RépubliqueFrançaise: Santé Publique France. Bulletin épidémiologique grippe, semaine 10. Saison 2019-2020. Available at https://www.santepubliquefrance.fr/maladies-et-traumatismes/maladies-et-infections-respiratoires/grippe/documents/bulletinnational/bulletin-epidemiologique-grippe-semaine-10.-saison-2019-2020 (French, last accessed on April 6 ${ }^{\text {th }}, 2020$ )

29. RépubliqueFrançaise: Santé Publique France. Bulletin épidémiologique grippe, semaine 11. Saison 2019-2020. Available at https://www.santepubliquefrance.fr/maladies-et-traumatismes/maladies-et-infections-respiratoires/grippe/documents/bulletinnational/bulletin-epidemiologique-grippe-semaine-11.-saison-2019-2020 (French, last accessed on April 6 ${ }^{\text {th }}, 2020$ )

30. Zainol Rashid Z, Othman SN, Abdul Samat MN, Ali UK, Wong KK. Diagnostic performance of COVID-19 serology assays. Malays J Pathol. 2020 Apr;42(1):13-21.

31. Yajun Y, Wang N, Ou X. Caution should be exercides for the detection of SARS-CoV-2, especially in the elderly. J Med Virol. 2020 Mar 30. doi: 10.1002/jmv.25796

32. Ai T, Yang Z, Hou H, Zhan C, Chen C, Lv W, Tao Q, Sun Z, Xia L. Correlation of Chest CTand RTPCR Testing in Coronavirus Disease 2019 (COVID-19) in China: A Report of 1014 Cases. 2020 Feb 26:200642. doi: 10.1148/radiol.2020200642

33. Zhang J, Litvinova M, Wang W, Wang Y, Deng X, Chen X, Li M, Zheng W, Yi L, Chen X, Wu Q, Liang Y, Wang X, Yang J, Sun K, Longini IM Jr, Halloran ME, Wu P, Cowling BJ, Merler S, Viboud C, Vespignani A, Ajelli M, Yu H. Evolving epidemiology and transmission dynamics of coronavirusdisease 2019 outside Hubei province, China: a descriptive and modelling study. Lancet Infect Dis. 2020 Apr 2. pii: S1473-3099(20)30230-9. doi: 10.1016/S1473-3099(20)30230-9

\section{Figures}




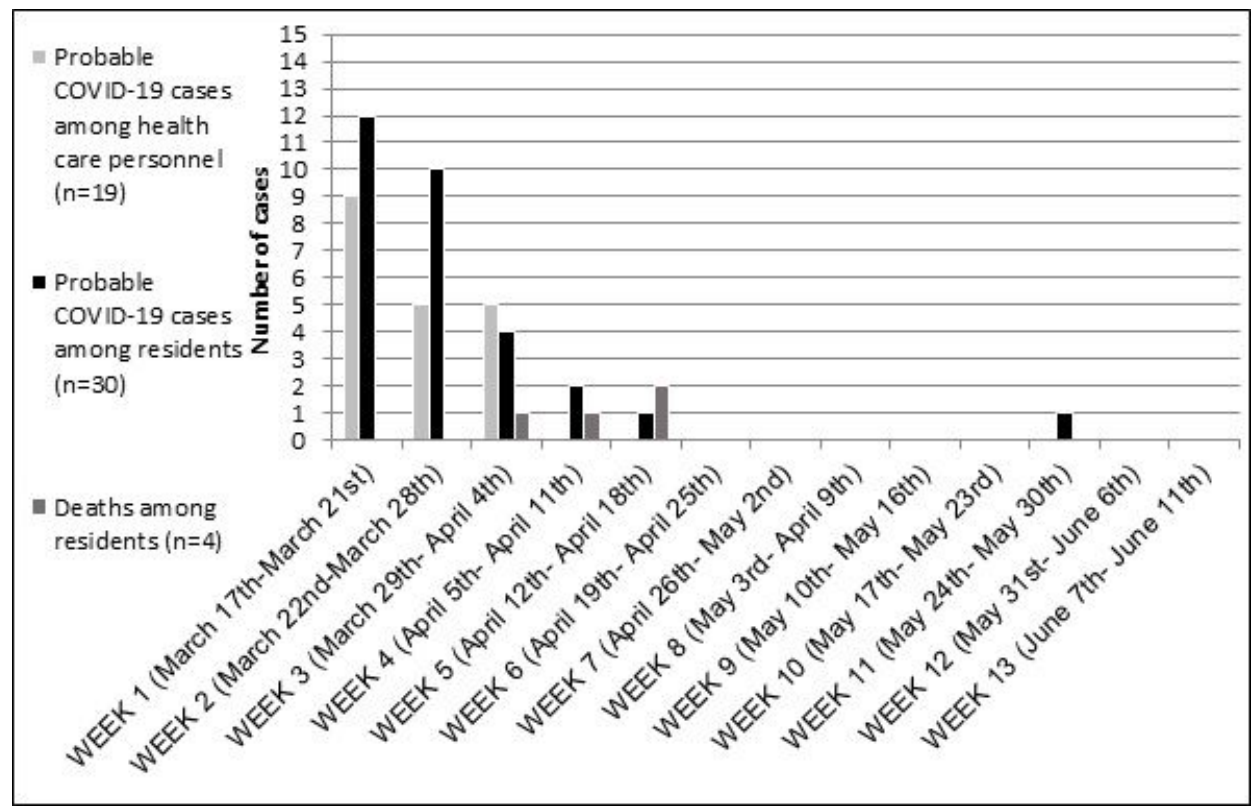

Figure 1

Evolution of new probable COVID-19 cases and deaths among health care personnel and residents from March 17th, 2020 to June 11th, 2020. NOTE: i) among health care personnel, 6/19 (31.5\%) probable COVID-19 cases were tested for COVID-19 by nasopharyngeal swab and classified as "confirmed cases" after positive result of SARS-Cov2 PCR; ii) all probable COVID-19 cases were tested negative for influenza virus infection by rapid flu test; iii) two patients developed COVID-19 symptoms early in March (March 2nd and 3rd, respectively) before the start of extraordinary measures and they were retrospectively classified as probable cases; iv) among residents only one probable case was tested for COVID-19 by nasopharyngeal swab and classified as "confirmed case" after positive result of SARS-Cov2 PCR; v) among dead residents,1/4 (25\%) was asymptomatic. 